\title{
14. \\ UROŠ DESNICA I NARODNA \\ RADIKALNA STRANKA U SPLITU \\ 1920-IH PREMA SPLITSKOJ PERIODICI
}

\section{Marijan Buljan}

UDK: 32-05Desnica, U.:329.21(497.5 Split)“192“

Izvorni znanstveni članak

Sažetak: Rad govori o djelovanju Uroša Desnice i Narodne radikalne stranke u Splitu od 1918. do 1929. Unatoč redovitim sudjelovanjima na izborima i izdavanju vlastitih novina stranka u navedenom razdoblju u Splitu nikada nije igrala važniju ulogu. Među njezinim istaknutijim članovima bio je Uroš Desnica, koji se isticao komentarima u splitskom tisku, polemikama s političkim suparnicima i djelovanjem u splitskoj Oblasnoj skupštini.

Ključne riječi: Uroš Desnica, Split, Narodna radikalna stranka, politički izbori, Država, splitska Oblasna skupština

\section{UvoD}

$\int$

arodna radikalna stranka $(\mathrm{NRS})^{1}$ imala je vodeću ulogu u parlamentarnom razdoblju prve jugoslavenske države, o čemu svjedoči njezino kontinuirano sudjelovanje u sastavu svih jugoslavenskih vlada, izuzev kraćeg razdoblja krajem 1924. godine. Ipak, u samom Splitu nikada nije polučila veći izborni uspjeh, iako je u izborima sudjelovala od prvih poslijeratnih izbora 1920., a od 1924. izdavala je stranačke novine Država. Zbog skromnog izbornog uspjeha često je koalirala s političkim strankama jugoslavenske orijentacije, no nezadovoljna jačanjem hrvatskih stranaka u Splitu gradu je spočitavala „antidržavno djelovanje“ i ,zaboravljanje“ ranijeg jugoslavenstva.

Uroš Desnica, otac Vladana Desnice, već otprije poznat zbog svoga političkog rada, imao je jednu od važnijih uloga u djelovanju mjesnih radikala, ${ }^{2}$ uz pravoslavnog paroha

1 Više o Narodnoj radikalnoj stranci vidi u: Ivo Banac, Nacionalno pitanje u Jugoslaviji: Porijeklo, povijest, politika, Zagreb 1995., 123-136; Hrvoje Matrović, Povijest Jugoslavije (1918 - 1991 - 2003), Zagreb 2003., 103-105.

2 Ne mogu sa sigurnošću reći da su svi navedeni imali stalno prebivalište u Splitu, no njihova imena najčešće nalazimo u događajima koji povezuju radikale i grad Split. 
Sergija Urukala, ${ }^{3}$ Josipa Jablanovića ${ }^{4}$ i Eduarda Grgića. ${ }^{5}$ Neko vrijeme bio je i predsjednik mjesnog odbora stranke. Često je putem Države polemizirao s političkim protivnicima, u prvom redu s Hrvatskom seljačkom strankom (HSS). Njihov sukob se intenzivirao nakon oblasnih izbora 1927., kada je Desnica postao član splitske Oblasne skupštine.

U ovom radu prikazat će se djelovanje Narodne radikalne stranke u Splitu od 1918. do 1929., s posebnim osvrtom na Uroša Desnicu, njegova politička shvaćanja i djelovanje u Splitu i splitskoj Oblasnoj skupštini.

\section{Počeci Narodne Radikalne stranke u Splitu i djelovanje Uroša Desnice}

Odvjetnik po struci i član predratne Srpske stranke ${ }^{6}$ Uroš Desnica i prije stvaranja prve jugoslavenske države nije imao zanemarivu ulogu u političkom životu Dalmacije. Uz to što je sudjelovao u donošenju Zadarske rezolucije ${ }^{7}$ bio je i članom zadarske Odvjetničke komore gotovo petnaest godina ${ }^{8}$ a u kasnijem razdoblju i predsjednikom odvjetničkog udruženja u Zadru. U završnoj fazi Prvoga svjetskog rata 1918. Desnica je obavljao nekoliko važnih funkcija pa tako bio članom Uprave Narodne organizacije Srba, Hrvata i Slovenaca u Dalmaciji, ${ }^{9}$ zamjenikom predsjednika i povjerenikom za pravosuđe u dalmatinskoj Zemaljskoj vladi ${ }^{10}$

3 Prota Sergije Urukalo (1878. - 1944.), pravoslavni svećenik. Uspostavljanjem pravoslavne parohije u Splitu imenovan je za njezinog prvog paroha. Bio je član masonske organizacije u Splitu i zastupnik Narodne radikalne stranke u Narodnoj skupštini. U Drugom svjetskom ratu je surađivao s četničkim pokretom. Vidi: Šimun Jurišić, Glasoviti Splićani, Split 2008., 183; Petar Požar, Znameniti i zaslužni Splićani, Split 2001., 321-322; Arsen Duplančrć, „Izvori za povijest masonstva u Splitu“, Croatica Christiana Periodica, 16/1992., br. 30, 104-115.

4 Josip (Cortelazzo) Jablanović (1875. - 1961.), političar i publicist. Po zanimanju pravnik, od 1918. istaknuti član Narodne radikalne stranke u Dalmaciji, a od 1932. do 1938. ban Primorske banovine. Vidi: Klara Pranjko, „Josip Jablanović", Hrvatski biografski leksikon (dalje: HBL), sv. VI, Zagreb 2005., 212.

5 Eduard Grgić (1863. - 1954.), političar i gospodarstvenik. Prije rata podržavao Narodnu hrvatsku stranku i Hrvatsku stranku i više godina bio zastupnik u Dalmatinskom saboru. Član uprave društava u Splitu, između ostalog, i predsjednik Trgovačko-obrtničke komore u Splitu. Za vrijeme 1920-ih je predsjednik ravnateljstva Jadranske plovidbe na Sušaku, a 1930-ih predsjednik Prve pučke dalmatinske banke u Splitu. Ivo Perić, „Eduard Grgić“, $H B L$, sv. V, Zagreb 2002., 179.

6 Srpska stranka osnovana je 1879. godine kao, između ostalog, i posljedica spora hrvatsko-srpskih političara u Narodnoj stranci oko pripadnosti Bosne i Hercegovine. Marjan Diklıć, Pravaštvo u Dalmaciji do kraja Prvog svjetskog rata, Zadar 1998., 61-62.; Antoni CetnarowiCZ, Narodni preporod u Dalmaciji: od slavenstva prema modernoj hrvatskoj i srpskoj nacionalnoj ideji, Zagreb 2006., 229-245.

7 Zadarskom su rezolucijom 1905. srpski političari dali potporu politici „novog kursa“ u zamjenu za priznanje narodne ravnopravnosti pa je time prestao dotadašnji sukob srpske i hrvatske politike. Vidi: Nikša STANČić, Hrvatska nacija i nacionalizam u 19. i 20. stoljeću, Zagreb 2002., 197-201; Jaroslav ŠIDAK i dr., Povijest hrvatskog naroda g. 1860-1914., Zagreb 1968., 222. Više o politici „novog kursa“ vidi u: Rene Lovrenčić, Geneza politike „novog kursa“, Zagreb 1972. Tereza Ganza-Aras donosi podatak da je Desnica bio član odbora koji je sastavio Zadarsku rezoluciju. Vidi: Tereza Ganza-Aras, Politika „novog kursa“ dalmatinskih pravaša oko Supila i Trumbića, Split 1992., 334.

8 Drago Roksandić, „Zatvaranje kruga: Dr Uroš Desnica (Obrovac, 28. VII 1874 - Split, 13. VII 1941)“, Spomenica dr Danice Milić (ur. Bojana Miljković-Katić), Beograd 2014., 304. Zadarska je općina jedina u Dalmaciji na vlasti imala Talijansku stranku. Vidi: Ante Bralić, Zadar u doba Prvog svjetskog rata, doktorska disertacija, Zadar 2005. Zdravka Jelaska Marijan, Grad i ljudi: Split 1918.-1941., Zagreb 2009., 66.

10 Čelnici Zemaljske vlade za Dalmaciju bili su Ivo Krstelj, Josip Smodlaka i Vjekoslav Škarica, a njihovi zamjenici Uroš Desnica, Jerko Machiedo i Prvislav Grisogono. Drago Roksandić, „Dr. Uroš Desnica 1918. - 1921.: životopisne nedoumice na raskrižju epoha“, Spalatumque dedit ortum: zbornik povodom desete godišnjice Odsjeka za povijest Filo- 
te jednim od članova Plenuma političara iz Dalmacije unutar središnjeg Narodnog vijeća. ${ }^{11}$ Ostaje otvoreno pitanje kakvu je ulogu vršio u zadarskom Narodnom vijeću. ${ }^{12}$

Talijansko zauzimanje istočne jadranske obale ${ }^{13}$ Desnicu je dočekalo u Zadru, odakle je uskoro interniran (od ožujka 1919. do početka 1920.), a nakon povratka iz internacije neko je vrijeme uređivao novine Naš list: od prosinca 1919. sve do lipnja 1920. Nakon toga Desnica pod prisilom napušta Zadar, premješta odvjetnički ured u Obrovac, a s obitelji odlazi u Split, u koji i „službeno“ preseljava $1927 .{ }^{14}$

Kada i zbog čega je Desnica postao članom NRS? Ranije je spomenuto da je bio jedan od članova predratne Srpske stranke, a prilikom jedne poslijeratne radikalske konferencije istaknuo je da su ujedinjenjem predratne dalmatinske stranke izgubile smisao postojanja. Od postojećih, naglasio je, samo su radikali pružali privlačnost zahvaljujući svojoj prošlosti, a revizijom programa stranka je otvorila vrata Slovencima i Hrvatima i time dobila „pečat univerzalnosti“". 15

Prve tragove NRS u splitskom tisku nalazimo u događajima vezanima uz izbore za Ustavotvornu skupštinu 1920. Nakon bezuspješne akcije Josipa Smodlake ${ }^{16}$ u stvaranju zajedničke izvanstranačke liste sastavljene od "najboljih i najsposobnijih ljudi “17 pojavile su se nove mogućnosti. Prva je bila da sve stranke za nositelja postave Antu Trumbića ${ }^{18}$ i na taj način pokažu složnost pred inozemstvom uoči nastavka pregovora s Italijom oko istočnojadranske obale, ${ }^{19}$ a druga, prema prijedlogu Demokratske stranke, ${ }^{20}$ da sam Trumbić, bez

zofskog fakulteta u Splitu (ur. Ivan Basić i Marko Rimac), Split 2014., 506. Više o nastanku i djelovanju dalmatinske Zemaljske vlade vidi u: Zdravka Jelaska Marijan, „Zemaljska vlada za Dalmaciju (2. studenoga 1918. - 20. siječnja 1919.)“, Godina 1918.: prethodnice, zbivanja, posljedice. Zbornik radova s mecunarodnoga znanstvenog skupa (ur. Zlatko Matijević), Zagreb 2010., 155-170; Zdravka Jelaska Marijan, „Uspostava Zemaljske vlade za Dalmaciju u Splitu 2. studenoga 1918“, 1918. u hrvatskoj povijesti: zbornik (ur. Romana Horvat), Zagreb 2012., $203-212$.

11 Z. Jelaska Marijan, Grad i ljudi, 68; Marina Štambuk-Škalić - Zlatko Matijević, „Narodno vijeće Slovenaca, Hrvata i Srba u Zagrebu 1918-1919. (izabrani dokumenti)“, Fontes: izvori za hrvatsku povijest, 14/2008., 87, 91; Zlatko Matıjević, „Kazalo osoba“, Fontes: izvori za hrvatsku povijest, 14/2008., 601.

12 Desnica je sebe svrstao u vodstvo zadarskog Narodnog vijeća, no podaci koje donosi Ante Bralić to opovrgavaju. Vidi: D. Roksandić, „Dr. Uroš Desnica 1918. - 1921.“, 502-503.

13 Više vidi u: Šime Peričıć, „Prilog poznavanju talijanske okupacije Dalmacije od 1918. do 1923. godine“, Radovi Instituta JAZU u Zadru, 20/1973. 7-48.

14 Roksandić ističe: „(...) izgleda da s odlaskom iz Zadra slabi njegova (Desničina, op. a.) motivacija da i dalje bude na isturenim položajima u stvaranju Kraljevine Srba, Hrvata i Slovenaca.“ D. Roksandić, „Zatvaranje kruga“, 304306.

15 „Konferencija Narodne radikalne stranke“, Država (Split), br. 238, 25. 8. 1926., 1-2.

16 Josip Smodlaka (1869. - 1956.), političar i odvjetnik. Prije Prvog svjetskog rata član Stranke prava u Dalmaciji i Hrvatske demokratske stranke (kasnije Hrvatske pučke napredne stranke), a neko vrijeme i zastupnik u Carevinskom vijeću. Za vrijeme Prvog svjetskog rata interniran, a završetkom rata postaje jedan od glavnih zagovornika ujedinjenja sa Srbijom i Crnom Gorom. Tijekom 1920-ih poslanik Kraljevine SHS u više zemalja, a 1940-ih istaknuti član partizanskog pokreta. Josip Smodlaka, Zapisi dra Josipa Smodlake (ur. Marko Kostrenčić), Zagreb 1972.; Ivo Perić - Hodimir Sirotković, „Politička djelatnost i politički lik Josipa Smodlake“, u: Josip Smodlaka, Izabrani spisi (prir. Ivo Perić i Hodimir Sirotković), Split 1989., 9-203.

17 „Akcija dr. Smodlake“, Novo doba (Split), br. 220, 29. 9. 1920., 1.

18 Ante Trumbić (1864. - 1938.), političar i odvjetnik. Jedan od osnivača Stranke prava u Dalmaciji, zastupnik u Dalmatinskom saboru i Carevinskom vijeću. Za vrijeme Prvog svjetskog rata predsjednik Jugoslavenskog odbora. Prvi ministar vanjskih poslova u Kraljevstvu SHS od 1918. do 1920. Istaknuti član Hrvatske zajednice i Hrvatske federalističke seljačke stranke 1920-ih, a potom i Hrvatske seljačke stranke. Vidi: Ivo Petranović, Ante Trumbić: politička shvaćanja i djelovanje, Split 1991.

19 Ferdo Šš́ı́, Jadransko pitanje na konferenciji mira u Parizu. Zbirka akata i dokumenata, Zagreb 1920.; Dragovan ŠEPIĆ, Italija, saveznici i jugoslavensko pitanje 1914-1918., Zagreb 1970.

20 Više o Demokratskoj stranci vidi u: Branislav GLigorijević, Demokratska stranka i politički odnosi u Kraljevini Srba, Hrvata i Slovenaca, Beograd 1970.; I. BANAC, Nacionalno pitanje u Jugoslaviji, 136-152. 
vlastitog stranačkog opredjeljenja, pristane biti kandidatom bilo koje liste prema vlastitom izboru. $^{21}$

Radikali su odbili i Smodlakin prijedlog i mogućnost da im nositelj bude Trumbić te su odlučili samostalno nastupiti u Splitu. ${ }^{22}$ Uoči izbora održali su manji stranački sastanak u Splitu, a na kandidatskoj listi stranke kao kvalificirani predstavnici postavljeni su Eduard Grgić i Uroš Desnica. ${ }^{23}$

Na prvim poslijeratnim izborima u Splitu radikali su osvojili skromnih 110 glasova, odnosno 3,03\% glasova svih birača. ${ }^{24}$ Novine nenaklonjene stranci tvrdile su da su glasove dobili od „bivših Italo-Srba, posjednika i srpskih frankovaca“. ${ }^{25}$ Ovo je bio najniži rezultat koji je stranka postigla u Splitu, a razloge tomu, uz neprihvaćanje stranačke politike, tražilo se u nedostatku prave predizborne kampanje i razočaranosti gotovo dvogodišnjim radikalskim sudjelovanjem na vlasti. Može ih se naći i u velikoj izbornoj apstinenciji, jer je u samomu Splitu na izbore izašlo $49,37 \%$ glasača. ${ }^{26}$

U vremenu do idućih parlamentarnih izbora NRS u Splitu nastavila je sa skromnim radom. Na rijetkim javnim nastupima stranke ponekad je istupao i sam Uroš Desnica. Primjerice, u govoru održanom sredinom 1921. prilikom proslave u čast regentu Aleksandru I. Karađorđeviću naglasio je da „ne dvoji da će Split, kao i dosad, i dalje biti čvrst bedem državnog i narodnog jedinstva “ ${ }^{27}$

Sredinom 1921. Desnica je predao ostavku na položaje u Pokrajinskoj vladi ${ }^{28}$ i prestao biti povjerenikom za unutarnje poslove i zamjenikom predsjednika. ${ }^{29}$ Drago Roksandić Desničinu ostavku tumači nezadovoljstvom zbog sve manjih ingerencija pokrajinske vlade i njezine marginalizacije te ga svrstava među prve koji su se „distancirali od službene politike“, iako bez promjene političkih shvaćanja, no također ističe i da ga je sigurno pogodilo što nije imenovan pokrajinskim namjesnikom za Dalmaciju. ${ }^{30}$

U studenome iste godine dalmatinski su radikali održali sastanak u Splitu pred „lijepim brojem prijatelja stranke iz grada i okolice“, na kojemu su istaknuli nužnost izgradnje Unske pruge ${ }^{31}$ i uređenja agrarnih odnosa u Dalmaciji. ${ }^{32}$ Tom prigodom izabran je odbor

$\overline{21}$ „Kandidatura dra Trumbića“, Novo doba, br. 216, 24. 9. 1920., 2; „Za pregovore“, Novo doba, br. 222, 2. 10. 1920. 2; „Pouzdani sastanak Dem. stranke“, Novo doba, br. 234, 16. 10. 1920., 3; „Sastanak Demokratske Stranke“, Novo doba, br. 238, 22. 10. 1920., 3; „Zaključak DS“, Novo doba, br. 240, 23. 10. 1920., 2.

22 „Radikalna stranka i dr. Trumbić", Novo doba, br. 253, 9. 11. 1920., 2.

23 ”Kandidatske liste u Dalmaciji“, Novo doba, br. 262, 19. 11. 1920., 3; „Na sastanku radikala“, Novo doba, br. 268, 26. 11. 1920., 3 .

24 „Izbori u Splitu“, Novo doba, br. 270, 29. 11. 1920., 1.

25 Sveučilišna knjižnica Split (dalje: SVKST), Trumbićeva ostavština (dalje: TO), M 567/11.

26 Od upisanih 7379 glasovala su 3636 glasača. Novo doba, br. 270, 29. 11. 1920., 1.

27 „Split regentu“, Hrvatska riječ (Split), br. 26, 1. 7. 1921., 1.

28 Zemaljska vlada ukinuta je u siječnju 1919., a umjesto nje uspostavljena je Pokrajinska vlada za Dalmaciju s manjim djelokrugom poslova. Z. Jelaska Marijan, Grad i ljudi, 97.

29 Ivo Krstelj je zbog biranja u Ustavotvornu skupštinu prestao biti predsjednik Pokrajinske vlade pa je njegovu dužnost neko vrijeme obavljao Desnica kao zamjenik sve do postavljanja Steve Metličića za predsjednika. D. Roksandić, „Dr. Uroš Desnica 1918. - 1921.“, 502; Z. Jelaska Marijan, Grad i ljudi, 111.

30 D. Roksandić, „Dr. Uroš Desnica 1918. - 1921.“, 502 i 506; D. Roksandić, „Zatvaranje kruga“, 306.

31 Unskom prugom planirano je povezivanje Splita sa Zagrebom i Beogradom. Iako su rasprave o potrebi njezine izgradnje trajale gotovo čitavo međuratno razdoblje, Unska pruga naposljetku je izgrađena tek poslije Drugog svjetskog rata. Vidi: Z. Jelaska Marijan, Grad i ljudi, 159-164.

32 Vidi: Zdenka Šmončić-Bоветко, „Agrarno pitanje u Dalmaciji između dva rata (1918-1941)“, Povijesni prilozi, 8/1989., 91-141. 


\section{Otvoreni odgovor profešuru Marulu u svrju gubitka lumbrele.}

(Zadnji slużbeni akt našeg potpresjednika.) -- Op. Ur.

Br. 3842,24 .

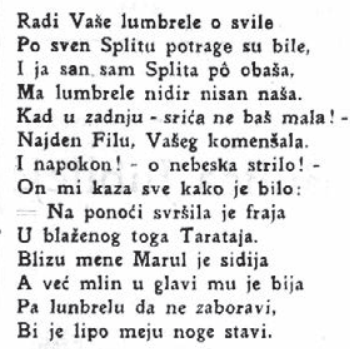

Radi Vaše lumbrele o svile Po sven Splitu potrage su bile, I ja san sam Splita pô obaša, Ma lumbrele nidir nisan naša. Kad u zadnju - sriça ne bas mala! Najden Filu, Vašeg komenšala. I napokon! - o nebeska strilo! On mi kaza sve kako je bilo: Na ponoci svrsila je fraja U blaženog toga Tarataja. Blizu mene Marul je sidija A vé́ mlin u glavi mu je bija $\mathrm{Pa}$ lunbrelu da ne zaboravi, $\mathrm{Bi}$ je lipo meju noge stavi.

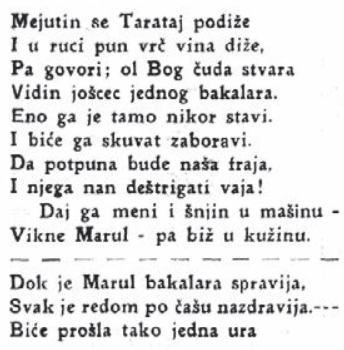

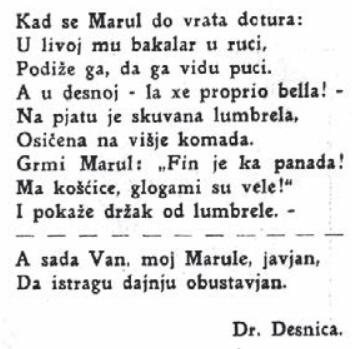

Dr. Desnica.

Sl. 1. Uroš Desnica na meti Duje Balavca u studenom 1921.

stranke od petnaest članova na čelu s Desnicom, a među članovima odbora nalazio se i Đuro Negrini - prvi predsjednik mjesne organizacije stranke u Splitu. ${ }^{33}$ Radikali su se u veljači 1922. javili u dva navrata: prvo je početkom mjeseca održano „radikalsko sijelo“ mjesnih pristaša, ${ }^{34}$ a krajem mjeseca Jablanović je u ime stranke govorio na zboru održanom protiv Memoranduma Hrvatskog bloka. ${ }^{35}$ Do kraja iste godine radikale ne nalazimo na značajnijim događajima, a ni sami nisu organizirali nikakva zbivanja kojima bi osigurali intenzivniju vezu s glasačima.

$\mathrm{Na}$ skupštinskim izborima 1923. radikali su izašli samostalno. Za nositelja južnog dalmatinskog okruga postavljen je Ljuba Jovanović, dok je za sreskog kandidata za Split postavljen Ante Štambuk. ${ }^{36}$ Jovanović je uoči samih izbora u govoru u Splitu pred radikalima i pristašama drugih stranaka obećao da će vlada učiniti sve za napredak Splita, čijem se ekonomskom napretku „radovao“. Prisutnost pristaša drugih stranaka navela je mjesno Novo doba ${ }^{37}$ na komentar da je to učinjeno namjerno zbog malog broja pristalica stranke. ${ }^{38}$

Proglas NRS-a upućen kotarskim biračima ističe Štambuka kao pravoga zagovaratelja budućih potreba i ,interesa ovoga lijepoga i važnoga našega Splita“. Svojim će radom NRS pokazati, zaključuje proglas, da „ima razumijevanja za veliku nacionalnu, kulturnu i privrednu važnost Splita, koji je u oslobođenju igrao važnu ulogu te tako stekao neizbrisive zasluge“.39

33 „Radikalski sastanak“, Novo doba, br. 258, 14. 11. 1921., 3; „Skupština radikala“, Jadran (Split), br. 86, 16. 11. 1921., 2-3; „Gjuro Negrini“, Država (Split), br. 310, 23. 7. 1927., 3.

34 „Radikalno sijelo“, Novo doba, br. 35, 13. 2. 1922., 3.

35 „Protestni zbor protiv memoranduma Hrv. Bloka“, Novo doba, br. 47, 27. 2. 1922., 1-2. Stjepan Radić je na međunarodnoj konferenciji zemalja u Genovi odlučio poslati memorandum s ciljem upoznavanja svijeta s hrvatskim pitanjem. U Splitu je održan protestni zbor protiv memoranduma na kojem su govorili vodeći članovi mjesnih demokrata, radikala i gradonačelnik Tartaglia. Vidi: Hrvoje Matković, Povijest Hrvatske seljačke stranke, Zagreb 1999. 99-103; Josip Horvat, Politička povijest Hrvatske, Zagreb 1989., 226-233.

36 „Izborne liste u južno - dalmatinskom srezu“, Novo doba, br. 41, 19. 2. 1923., 3.

37 Novo doba (1918. - 1941) bilo je najznačajnija novina međuratnog Splita. Glavni je urednik lista od njegova pokretanja 1918. do smrti 1927. bio Vinko Kisić, a potom je tu ulogu preuzeo Vinko Brajević. Više o Novom dobu vidi: Ivanka Kuić, „Novo doba - najvǎniji splitski i dalmatinski list između dva rata“, Kulturna baština, 39/2013., 113-138.

38 „Ministar vjera u Splitu“, Novo doba, br. 59, 12. 3. 1923., 4; „Govor g. ministra Ljube Jovanovića“, Novo doba, br. 59, 12. 3. 1923., 2; „Izborni govor g. Ljube Jovanovića“, Novo doba, br. 63, 16. 3. 1923., 1.

39 SVKST, TO, M 568/11. 
Na parlamentarnim izborima 1923. NRS je u Splitu osvojila 329 glasova, odnosno $8,04 \%$ glasova ${ }^{40}$ To je bilo gotovo tri puta više glasova nego na ranijim izborima, a glasove su u Splitu vjerojatno dobili na račun demokrata, koji su u ostatku države, iako s većim brojem glasova u odnosu na 1920., ipak znatno manje porasli nego radikali. ${ }^{41} \mathrm{U}$ narednim izborima na području Splita ovaj rezultat definirat će čvrstu radikalsku biračku bazu.

Jedan od izabranih radikalskih zastupnika na ovim izborima bio je i Uroš Desnica te je od ožujka do listopada 1923. djelovao u Narodnoj skupštini. Zanimljivo je da je tada odbio Pašićevu ponudu da postane ministar za socijalnu politiku u njegovoj vladi. ${ }^{42}$

Novi korak u djelovanju stranke u Splitu bilo je izdavanje Države, glasila Okružnog odbora stranke u Splitu, koje je ispočetka izlazilo dva puta tjedno, počevši od travnja $1924 .{ }^{43}$ $\mathrm{Na}$ ovaj način stranka više nije ovisila samo o (često nenaklonjenim) izvještajima drugih novina, no pravi učinak novog djelovanja stranke pokazali su novi izbori u Splitu. Jedan od čestih autora članaka u Državi bio je i sam Desnica, koji je, nerijetko pod pseudonimom, govorio o aktualnoj političkoj situaciji. Tako je do novih izbora govorio o vodećim političkim ličnostima, pri čemu je još 1924. tvrdio da će najveća Pašićeva pobjeda biti ako se Radić odrekne svoga programa i prihvati narodno i državno jedinstvo. ${ }^{44}$ Prema Radiću je bio posebno kritičan te ga je držao „simbolom protusrpskog raspoloženja zaboravnog hrvatskog plemena“, 45 odnosno „najkonfuznijim, najpraznijim i najtrivijalnijim frazerom“, čijeg se vodstva hrvatski narod mora osloboditi. ${ }^{46}$

Odnos radikala prema Splitu bio je posebno zanimljiv. Za razliku od ranijeg Desničinog nazivanja grada „bedemom narodnog i državnog jedinstva“, jačanje HSS-a i uvijek jaka ličnost Ante Trumbića radikale su brinuli pa su izražavali nadu da će se naći „čovjek ili stranka“ (u prvom redu radikalna, dakako) koji će srušiti „mreže političkih pauka“ razasutih Splitom i tako gradu vratiti „njegov stari nacionalni nimbus“ ${ }^{47}$ Prilikom raznih jugoslavenskih svečanosti, poput obilježavanja Rapalskog dana ili proslave Vidovdana Splitu je spočitavano da je „zaboravio na svoje jugoslavenstvo i nacionalnu svijest kojom se nekad ponosio“, odnosno da je pod Radićem i Trumbićem nestalo „pravog i čistog hrvatstva“ te, naposljetku, da je pošao „stopama separatističkog Zagreba““48

\footnotetext{
40 SVKST, TO, M 568/11; „Rezultat u gradovima. Grad Split“, Novo doba, br. 65, 19. 3. 1923., 3.

41 Na izborima za Ustavotvornu skupštinu 1920. demokrati su dobili oko 320 000, a radikali oko 285000 glasova. Na skupštinskim izborima 1923. demokrati su osvojili oko 400000 glasova, a radikali oko 562 000. J. Horvat, Politička povijest Hrvatske, 196-197, 247-248.

42 D. Roksandić, „Zatvaranje kruga“, 307.

43 Prvi broj Države izašao je 16. 4. 1924.

44 „Pašić i Radić“, Država, br. 1, 16. 4. 1924., 1-2.

45 „Zakon mržnje“, Država, br. 39, 30. 8. 1924., 1.

46 "Junak našeg doba“, Država, br. 70, 20. 12. 1924., 1.

47 "Split nekada i sada“, Država, br. 34., 13. 8. 1924., 3

48 Isto; „Slava narodnom mučeniku“, Država, br. 48, 1. 10. 1924., 3; „Čujte Hrvati u Istri! Splićani, gdje vam je ponos!“, Država, br. 62, 22. 11. 1924., 1; „Proslava Vidovdana“, Država, br. 124, 1. 7. 1925., 3.;
} 


\section{SKUPŠTINSKI, OPĆINSKI I OBLASNI IZBORI TE ODNOS PREMA SPLitu}

Radikali su na skupštinskim izborima 1925. izašli sa Samostalnom demokratskom strankom (SDS), ${ }^{49}$ nastaloj 1924. izdvajanjem iz Demokratske stranke, pod imenom Nacionalni blok..$^{50}$ Nositeljem zajedničke liste u južnom izbornom okrugu postavljen je Prvislav Grisogono, ${ }^{51}$ a kandidatom za spojene kotareve Split-Sinj Mirko Tripalo. Država je tvrdila da u splitskom dijelu koalicije vlada „potpuna jednoglasnost i složnost “, 52 a predizborni zbor uvjerio ju je da je Split „snažno manifestirao jaku ideju narodnog jedinstva i ljubavi prema zajedničkoj otadžbini i viteškom kralju“..$^{33}$

No uoči samih izbora radikali su optužili Novo doba da je stalnim kritiziranjem režima odgovorno za to što će Split „kroz izborne žare progovoriti radićevski i komunistički“.54 Novo doba je optužbe odbacilo, a opredjeljenje „,najjugoslavenskijeg grada“ za Radića tumačilo je pogrešnom državnom i ekonomskom politikom, koja je za Split značila još uvijek nedovršen željeznički spoj i nesređenu luku. ${ }^{55}$ Između 700 i 800 glasača Nacionalnog bloka, vjeruje Država u odgovoru, „bit će malena ali svjesna afirmacija inteligencije“.56

Na skupštinskim izborima 1925. NRS je kao sastavnica Nacionalnog bloka u Splitu dobila 930 glasova, odnosno 19,32\% svih glasova. ${ }^{57}$ Rezultatima je Država bila oduševljena te je istaknula da je riječ o brojci koja „zahtijeva poštovanje“ $\mathrm{i}$ koja pokazuje da je ideja nacionalnog unitarizma i dalje jaka u Splitu. ${ }^{58}$ Ipak, uvjerljiva pobjeda Radićeva HSS-a ${ }^{59}$ nagnala ju je da „sa žaljenjem konstatira“ kako je Split „otišao u komunističko-radićevski tabor“, čiji se politički pogledi i ciljevi mogu ostvariti „samo po cijenu rasula ove države“. ${ }^{60}$

Do idućih izbora radikali su odbijali optužbe drugih stranaka za svojevrsno „neraspoloženje" stranke prema Splitu, manifestirano prilikom dolaska kraljevske obitelji, ${ }^{11}$ a održanu „radikalsku večer“ držali su znakom ,jačanja ideja stranke u Splitu“. ${ }^{62}$

49 Više vidi u: Hrvoje Matкović, Svetozar Pribićević i Samostalna Demokratska Stranka do šestojanuarske diktature, Zagreb 1972.

50 „Udruženim silama na izbore za obranu najviših državnih i narodnih ideala“, Država, br. 72, 27. 12. 1924., 1.

51 Prvislav Grisogono (1879. - 1969.), odvjetnik i političar. Prije Prvog svjetskog rata blizak Hrvatskoj pučkoj naprednoj stranci, a za vrijeme rata interniran. Jedan od istaknutijih članova Demokratske stranke, a od 1924. Samostalne demokratske stranke. Ministar više puta 1920-ih, u razdoblju diktature podržava režim zbog čega je postavljen za izaslanika u Pragu i Varšavi. Mladen Švab, „Prvislav Grisogono“, HBL, sv. V, Zagreb 2005., 218-219. „Na izbore punom verom i sigurnošću u pobedu“, Država, br. 73, 31. 12. 1924., 1; „Liste Nacijonalnog Bloka“, Država, br. 77, 14. 1. 1925., 1; „Predane izborne liste“, Novo doba, br. 9, 13. 1. 1925., 5.

53 „Manifestacija narodnoga i državnoga jedinstva“, Država, br. 74, 3. 1. 1925., 1; „Radikali i sam. demokrati“, Novo doba, br. 2, 3. 1. 1925., 4.

54 „Aminaši - Novom Dobu“, Država, br. 79, 21. 1. 1925., 1; „Za koga da glasamo? Odgovor Novom Dobu“, Država, br. 84, 7. 2. 1925., 1.

55 „Uzroci političkom raspoloženju širokih slojeva“, Novo doba, br. 44, 21. 2. 1925., 1.

56 "Za koga da glasamo? Odgovor Novom Dobu“, Država, br. 84, 7. 2. 1925., 1.

57 „Izbori u Splitu“, Novo doba, br. 34, 10. 2. 1925., 1.

58 „Pobjeda državotvnorne ideje“, Država, posebno izdanje prigodom izbora 1925.

59 HSS je na izborima dobila 1888 glasova, odnosno gotovo $40 \%$ svih glasova. Novo doba, br. 34, 10. 2. 1925 ., 1.

60 „Split na izborima“, Država, br. 87, 18. 2. 1925., 1.

61 „Osvrt na osvrt“, Država, br. 154, 14. 10. 1925., 2; „Za spomeniku Kralju Oslobodiocu“, Država, br. 155, 17. 10. 1925., 3.

62 „Radikalsko veče: Manifestacija radikalske snage“, Država, br. 187, 13. 2. 1926., 3. 
U svibnju 1926., nakon višegodišnjih odgađanja, konačno je zakazano održavanje općinskih izbora u Dalmaciji. ${ }^{63}$ Mjesni su radikali uoči izbora bili spremni surađivati sa strankama koje „pružaju jamstvo“ za uspješnu komunalnu politiku u skladu s narodnim i državnim jedinstvom pa su postali dio šire koalicije imena Općinski blok seljaka i građana (Građanski blok $)^{64}$ na čelu s aktualnim gradonačelnikom Ivom Tartagliom. ${ }^{65} \mathrm{Od}$ istaknutijih imena NRS-a Eduard Grgić je zauzimao peto mjesto na listi kandidata Građanskog bloka.

$\mathrm{Na}$ izborima je Građanski blok dobio deset mandata, iako je Država isticala „najnepovoljniji trenutak" održavanja izbora i apstinenciju tisuća radikalskih činovnika. ${ }^{66}$ Radikali su se pribojavali mogućnosti da hrvatske stranke preuzmu upravu u gradu i upozoravali su na „štetnost dolaska nesposobnih ljudi“ i „teškog udarca za Split“, osobito nakon bezuspješne konstituirajuće sjednice. Do toga nije došlo ni na drugoj sjednici, kada je sporazumom Građanskog bloka i Hrvatske federalističke seljačke stranke ${ }^{67}$ odlučeno da će Tartaglia i dalje biti gradonačelnik, dok je Grgić postao član općinske uprave. ${ }^{68}$

Osvrnemo li se malo na „najnepovoljniji trenutak“, važno je upozoriti da novu vladu od srpnja 1925. čine NRS i HSS nakon Radićeva političkog „zaokreta“. Uroš Desnica u Državi se više puta osvrtao na novog koalicijskog partnera, upozoravajući da ga lojalnost i disciplina prema stranci te želja za sporazumom sprječavaju u iskrenom iznošenju svoga mišljenja ${ }^{69}$ Kada su se odnosi počeli komplicirati, tvrdio je da HSS nije iskrena u sporazumu

$\overline{63} \mathrm{Na}$ izborima su hrvatske stranke u prvom redu isticale političku komponentu, a potom lokalnu politiku. Naspram njih, mjesni demokrati zagovarali su stvaranje jedne zajedničke izborne liste, bez obzira na stranačku pripadnost, koja bi okupila najsposobnije građane. Vidi: „Zaključak Jugoslavenske demokratske stranke o općinskim izborima“, Pučki list (Split), br. 1., 1. 1. 1926., 3; „Akcija DS“, Jadranska pošta (Split), br. 213, 7. 4. 1926., 2.

64 Prema radikalskoj Državi Građanski blok činili su: radikali, nezavisni i davidovićevci; prema izbornom plakatu koji donosi Petar Krolo: Pokrajinski težački savez, radikali, demokrati, Nezavisna građanska grupa i Nezavisna grupa hrvatskih obrtnika, dok Novo doba, uz navedene, govori još i o Oblasnom odboru Saveza zemljoradnika. Vidi: „Općinski izbori i komunalna politika“, Novo doba, br. 83, 10. 4. 1926., 3; „Liste za splitsku općinu“, Novo doba, br. 98 , 28. 4. 1926., 4; „Splitski općinski izborni blok seljana i građana“, Novo doba, br. 100, 30. 4. 1926., 4; „Prvi izborni proglas u Splitu“, Jadranska pošta, br. 239, 8. 5. 1926., 2; „Srez Split“, Država, br. 213, 19. 5. 1926., 3; Ljubo Boвan, „Prilozi za političku biografiju don Frane Bulića (1914-1934), Radovi Zavoda za hrvatsku povijest, 18/1985., 180; Petar Krolo, „Ante Trumbić i općinski izbori u Splitu 1926. i 1928. godine“, Život i djelo Ante Trumbića: prilozi sa znanstvenog skupa (ur. Ljubo Boban i Ivan Jelić), Zagreb 1991., 139; Z. Jelaska Marijan, Grad i ljudi, 120.

65 Ivo Tartaglia (1880. - 1949.), odvjetnik, političar, pisac i kritičar. Istaknuti član Hrvatske pučke napredne stranke prije Prvog svjetskog rata, za vrijeme rata interniran. Od 1918. do 1928. gradonačelnik Splita u razdoblju kada grad doživljava značajan gospodarski i urbanistički procvat. Od 1929. do 1932. ban Primorske banovine, a potom se sve više približava politici HSS-a pa pokreće Jadranski dnevnik koji podržava njegovu politiku. Nakon Drugog svjetskog rata komunistička ga vlast iz političkih razloga osuđuje na višegodišnju zatvorsku kaznu. Vidi: Norka MACHIEDO Mladinić, Životni put Ive Tartaglie, Split 2001.; Aleksandar JAKIR - Norka Machiedo-Mladinić (ur.), Izabrani spisi Ive Tartaglie, Split 2013. Jadranska pošta, br. 245, 17. 5. 1926., 1; „Zar i Dalmacija izručena radićevcima“, Država, br. 213, 19. 5. 1926., 2. Više o stranci vidi u: Ljubomir ANTić, „Hrvatska federalistička seljačka stranka“, Radovi instituta za hrvatsku povijest, 15/1982., 163-222.

68 SVKST, TO, M 571/1-16; SVKST, TO, M 588/79; SVKST, Zapisnici sa sjednica općinskog vijeća u Splitu (dalje: ZOV) od 25. svibnja 1926., M - 611/II i; „Pitanje općinske uprave u Splitu“, Država, br. 213, 19. 5. 1926., 4; „Konstituiranje općinskih uprava“, Država, br. 214, 22. 5. 1926., 3; „Split bez općinske uprave“, Novo doba, br. $120,26$. 5. 1926., 1; „Oko općinske uprave u Splitu“, Jadranska pošta, br. 255, 28. 5. 1926., 3; „Prijedlog HSS i HPS HFSS-u“, Jadranska pošta, br. 256, 29. 5. 1926., 3; „Oko općinske uprave“, Jadranska pošta, br. 258, 1. 6. 1926., 3; „Konstituiranje nove Općinske Uprave u Splitu“, Novo doba, br. 127, 3. 6. 1926., 3-4; P. Krolo, „Ante Trumbić“, 141-146; Lj. Boban, „Prilozi za političku biografiju don Frane Bulića“, 108-110, 113-116.

69 „Sporazum i provincija“, Država, br. 118, 10. 6. 1925., 1-2; „Razgovor s Urošom Desnicom“, Država, br. $138,19$. 8. 1925., 1; „Ćist račun, duga ljubav“, Država, br. 150, 29. 9. 1925., 3-4. 
i da Radić vodi protusrpsku politiku te da je politika sporazuma laž od njezina samog početka. ${ }^{70}$ Nakon Radićeva govora u Makarskoj, u kojem je kritizirao dalmatinske radikale, Desnica je oštro reagirao pa je Radića nazvao „lažljivcem, klevetnikom i izdajicom domovine“, 71 a drugom prilikom ,zlobnom budalom, utvrđenim austrijskim robom i agentom boljševičke Moskve“.72

Obljetnica dolaska srpske vojske u Split u studenome ${ }^{73}$ dovela je do nove polemike između Države i Novog doba. Država se uoči obilježavanja pitala hoće li „nacionalni Split“ proslaviti taj dan. ${ }^{74}$ Novo doba je to držalo provokacijom pa je istaknulo da će Split taj dan proslaviti patriotski kao što je slavio „i prije dolaska ovih koji vode Državu a gledaju samo stranačke interese “. ${ }^{75}$ Ova manja polemika samo je nastavak ranijeg kompleksnog odnosa između Novog doba i Države, koji su tijekom 1920-ih obično imali zajedničkog neprijatelja - Radića, no odnos prema Splitu bio je glavni izvor njihova sukoba, koji će se, uz Desničino sudjelovanje, rasplamsati polovicom 1928.

\section{SPLITSKA OBLASNA SKUPŠTINA I PARLAMENTARNI IZBORI I927.}

Na oblasnim izborima $19277^{76}$ mjesni su radikali ponovno nastupili zajedno sa SDS-om, sada pod imenom "Jugoslavenski blok" na čelu s Dujmom Mikačićem. ${ }^{77}$ Cilj stranke je bio doprinijeti „prema svojoj snazi, dobrom izbornom uspjehu na korist Splita“.78 Mikačićev govor na predizbornom skupu o ugrožavanju hrvatstva Splita ako se ne poveže s Beogradom radikalima je značilo „ukazivanje na pogrešan put kojim je pošao Split“ ${ }^{79}$ U odnosu na prethodne izbore koalicija je porasla pa je sada dobila 1034 glasa, odnosno $24,37 \% .{ }^{80}$

Jedan od zastupnika splitske Oblasne skupštine postao je Uroš Desnica, koji je ušao kao kandidat stranke u srezu Benkovac. ${ }^{81}$ Splitska Oblasna skupština tijekom 1927. i 1928. postala je nova borbena „arena“ političkih stranaka, u kojoj se Desnica posebno isticao. Su-

\footnotetext{
„Hajka na Velikog Župana“, Država, br. 162, 11. 11. 1925., 1; „Da se razumijemo“, Država, br. 216, 29. 5. 1926., 1.

„Pismo Uroša Desnice Stjepanu Radiću“, Država, br. 227, 10. 7. 1926., 1.

72 „Sveti Jovan pred sudom“, Država, br. 265, 4. 12. 1926., 1.

73 Srpska je vojska došla u Split 20. studenog 1918., što se svake godine obilježavalo. Vidi: Novo doba, br. 166, 22. 11. 1918., 1-3.

74 „Prije osam godina“, Država, br. 260, 17. 11. 1926., 3.

75 "Godišnjica dolaska srpske vojske“, Novo doba, br. 268, 19. 11. 1926., 4; „Neumjesne primjedbe Novog Doba“, Država, br. 261, 20. 11. 1926., 3; „Nisu neumjesne primjedbe Novog Doba“, Novo doba, br. 271, 23. 11. 1926., 4.

76 Vidovdanskim je ustavom država podijeljena na 33 oblasti kojima su upravljale Oblasne skupštine. Izbori za njihov sastav konačno su određeni za siječanj 1927.

77 Dujam Mikačić (1865. - 1933.), općinski tajnik. U splitskoj je općini dug niz godina vršio razne funkcije poput dnevničara, općinskog tajnika i savjetnika. Petar PožAr, Znameniti i zaslužni Splićani, 224.

78 „Izborno kretanje“, Država, br. 267, 15. 12. 1926., 3; „Polemika Grisogono - Majstrović: izjava g. Dr. Josipa Jablanovića", Jadranska pošta, br. 426, 22. 12. 1926., 2.

79 „Izborna skupština jugoslavenske splitske liste“, Jadranska pošta, br. 439, 10. 2. 1927., 2; „Izborna skupština Jugoslavenskog bloka“, Novo doba, br. 6, 10. 1. 1927., 4; „U Splitu“, Država, br. 273, 12. 1. 1927., 2; „Proglas jugoslavenskog bloka za grad Splita“, Jadranska pošta, br. 447., 19. 1. 1927., 2.;

80 „Proglas jugoslavenskog bloka za grad Splita“, Jadranska pošta, br. 447., 19. 1. 1927., 2; „Rezultati izbora za Oblasne skupštine“, Jadranska pošta, br. 451, 24. 1. 1927., 1.

81 „Rezultati jučerašnjih oblasnih izbora“, Novo doba, br. 18, 24. 1. 1927., 1.
} 
kobi su počeli na samom početku zasjedanja, jer je HSS od 49 mogućih mandata osvojila njih 26, što joj je omogućilo da izabere predsjednika i formira oblasne odbore. ${ }^{82}$ Desnica se za vrijeme prvog zasjedanja Skupštine žestoko suprotstavljao HSS-ovoj većini i optuživao ju za nepoznavanje zakonskih propisa. ${ }^{83} \mathrm{U}$ više navrata situacija je bila na rubu fizičkih obračuna, a smirivanju nije pomagao Desnica, koji je HSS-ove zastupnike nazivao boljševicima ili im se otvoreno izrugivao. ${ }^{84}$ Drugom je prilikom inicirao da prisutna opozicija napusti sjednicu, ${ }^{85}$ zbog čega je Jadranska pošta isticala da je za skupštinsku većinu Desnica oporbeni leader terrible. ${ }^{86}$ Spomenuta Jadranska pošta, iako opozicijsko glasilo, Desničinu kritiku budžeta u govoru od gotovo tri sata srdačno je pozdravila. ${ }^{87}$ U govoru je Desnica „prema parlamentarnom običaju“ kritizirao budžet, ali i rad oblasne većine, za koji je tvrdio da je većinom bio nezakonit te da baca mrlju na svijetlu tradiciju (Dalmatinskog sabora M.B.). Razlog tome vidi što jedna klasa (seljaci) upravlja svime, no ne samostalno, nego uz poslušnost prema vodstvu stranke. Većinski HSS, stoga, optužuje za kukavičluk, a situaciju u Oblasnoj skupštini naziva „prokonzularnim sistemom“. ${ }^{88}$

Drugi splitski dnevnik Novo doba opširno je donosio Desničine govore uz popratne komentare odobravanja jer je i samo vjerovalo da seljaci moraju svoje mjesto prepustiti kompetentnijim zastupnicima u skupštini. ${ }^{89}$ Sam Desnica u razgovoru za Državu, što je prenijelo i

$\overline{82}$ Novo doba u dva navrata donosi drugačiji sastav oblasnih zastupnika prema strankama. U prvom slučaju tvrdi da od ostalih stranaka NRS ima 7 mandata, SDS 3, disidenti HSS-a 3, zemljoradnici 2, HFSS 1, HPS 1, komunisti 1 i neopredijeljeni 1 mandat. Pod terminom „neopredijeljeni“ Novo doba svrstava Dujma Mikačića, no držim da se Mikačić kao kandidat „Jugoslavenskog bloka“ mora pridati bilo radikalima, bilo SDS-u. „Oblasni izbori u Dalmaciji“, Novo doba, br. 19, 25. 1. 1927., 4. Drugom prilikom Novo doba tvrdi da HSS ima 26, NRS 8, HSS i disidenti radnici 4, SDS 5, HFSS 1, HPS 1, Jugoslavenska demokratska stranka 1 i neopredijeljeni (ponovno D. Mikačić) 1 mandat. „Narodni poslanici splitske Oblasne skupštine“, Novo doba, br. 42, 21. 2. 1927., 4.

83 "Prva sjednica splitske oblasne skupštine“, Jadranska pošta, br. 478, 24. 2. 1927., 1. Prema pisanju Novog doba jedna od Desničinih rečenica na prvom danu zasjedanja bila je: „...treba priučiti ovu Oblasnu Skupštinu na strogu zakonitost.“ Vidi: „Prvi dan Splitske Oblasne Skupštine - popodne“, Novo doba, br. 45, 24. 2. 1927., 3. U kasnijim navratima Desnica je isticao da se u Skupštini ležerno radi i shvaća dužnost pa je poručio da treba „manje partizanstva, a više pozitivnog rada“. Vidi: „Sjednica Oblasne Skupštine“, Novo doba, br. 107, 9. 5. 1927., 3.

84 „Skupštinska većina mijenja svoje držanje“, Jadranska pošta, br. 480, 26. 2. 1927., 2; „Ponovna bura u Oblasnoj skupštini“, Jadranska pošta, br. 520., 14. 4. 1927., str. 2. Novo doba donosi: „Dr. Desnica diže se i razmahavši se rukama, dobacuje jakim glasom prema Radićevcima: Pa sinoć ste tražili da Vam se dadu novci. Dogodilo se preko noći nešto čudna. Da nije došao neki gospodin koji je donio drugu naredbu? (...) U ovoj buci koja postaje svakim časom sve to jača čuje se jedino jaki glas dra Desnice koji nad svim dominira: - Dajte nam razlog! (...) Dr. Desnica (...) napušta svoje mjesto i leti prema Radićevcima to im dobacuje jakim glasom da se cijela dvorana trese: - Boljševici!" Vidi: „Prva burna sjednica naše Oblasne Skupštine“, Novo doba, br. 46, 25. 2. 1927., 4.

85 „Subota u oblasnoj skupštini“, Jadranska pošta, br. 481, 28. 2. 1927., 2; „Apstinencija cijele opozicije u Oblasnoj Skupštini“, Novo doba, br. 48, 28. 2. 1927., 3; „Završetak prvog zasjedanja splitske oblasne skupštine“, Jadranska pošta, br. 482, 1. 3. 1927., 1.

86 „Iz Oblasne skupštine“, Jadranska pošta, br. 543, 12. 5. 1927., 1.

87 „[Uroš Desnica] nastupio je u proračunskoj debati kao stari i rutinizirani parlamentarac, odličan pravnik i poznavalac naših posebnih prilika i konačno kao prvorazredan govornik koji nema retoričku gestu, ali posjeduje sve oblike sintetičkog i jasnog mislioca, koji se umije uvijek najpravilnije i stilski otmeno (!) da izrazi. On je stavku po stavku dokazivao, da je budget promašen i slabo izrađen te je najavio da će glasovati protiv. Njegov govor bio je tako opširan, da ga se mora štampati u posebnoj brošuri ako se želi dobiti jasan pregled njegovih izvoda u budgetu prama predlogu(!) oblasne većine." Vidi: „Iz Oblasne skupštine“, Jadranska pošta, br. 543, 12. 5. 1927., 1. Oblasni budžet naposljetku je prihvaćen glasovima većine. „Iz Oblasne skupštine“, Jadranska pošta, br. 556, 28. 5. $1927 ., 6$.

88 „Budžetska debata u Oblasnoj Skupštini“, Novo doba, br. 115, 18. 5. 1927., 4; „Budžetska debata u Oblasnoj Skupštini“, Novo doba, br. 116, 19. 5. 1927., 3-4.

89 „Pred sutrašnji sastanak Oblasne skupštine“, Novo doba, br. 43, 22. 2. 1927., 3; „Prvi rezultati Splitske Obl. skupštine“, Novo doba, br. 47, 26. 2. 1927., 2. U Državi je Desnica (nepotpisan) skupštinu nazvao „preslikom sela“. Vidi: „Doći će!“, Država, br. 303, 14. 5. 1927., 1. 
Novo doba, istaknuo je da će skupštinska većina s vremenom shvatiti da ne može upravljati splitskom oblasti bez suradnje ostalih stranaka, no da je pitanje hoće li tada opozicija htjeti surađivati. ${ }^{0}$ Ipak, u prvom zasjedanju Oblasne skupštine bilo je nekoliko zanimljivosti. Prva je to što je splitska Oblasna skupština jednoglasno izglasala rezoluciju protiv Nettunskih konvencija. ${ }^{91}$ Druga zanimlijivost je što je Desnica glasovao za prijedlog Oblasnog odbora da se novac udijeli hrvatskom sokolstvu, a svoj potez motivirao je tvrdnjom da on stoji na načelu potpunog jedinstva Srba, Hrvata i Slovenaca te da vjeruje da će u budućnosti Oblasni odbor isto tako novac dati nekom srpskom društvu. U nastavku sjednice istaknuo je da će uložiti sav svoj autoritet da izbaci „ološ“ iz NRS, no u raspravi se gotovo fizički sukobio $s$ Josipom Drezgom, zastupnikom HSS-ovih disidenata. ${ }^{92}$ Prilikom zaključenja prvog zasjedanja Oblasne skupštine Novo doba je objavilo kratak razgovor s Desnicom, u kojemu je ovaj branio podjele na oblasti i tvrdio da su prečanske oblasti slabije iskoristile mogućnosti za razliku od srpskih, a rad splitske Oblasne skupštine opisao je kao „jalov, beskoristan, direktno štetan po narod, državu i reputaciju“.93

U nastavku godine radikali su se protivili Radićevu prijedlogu o Dubrovniku kao središtu ujedinjenih splitske i dubrovačke oblasti, vjerujući da središte mora biti Split s „geografskog, privrednog, socijalnog i kulturnog gledišta“ kao najveća morska luka i središte pomorskog života. ${ }^{94} \mathrm{Na}$ sastanku mjesne organizacije stranke u srpnju 1927. izabrana je nova uprava. Jednoglasno je, prema izvješću Jadranske pošte, za predsjednika izabran Uroš Desnica, koji se u to vrijeme, kako je ranije spomenuto, s obitelji preselio u Split pa je moguće da je zbog toga i izabran na ovo mjesto. ${ }^{95}$ No čini se da se nije dugo zadržao na navedenom položaju jer se u jednom izvještaju iz veljače 1928. kao predsjednik mjesne organizacije spominje Jablanović. ${ }^{6}$

Novi parlamentarni izbori zakazani su za rujan 1927. Za razliku od ranijih izbora radikali su sada istupili samostalno, prvi put od $1923 .{ }^{97}$ Nositelj radikalske liste u južnom

$\overline{90}$ „Naša Splitska oblasna skupština i njena većina“, Država, br. 284, 2. 3. 1927., 1; „Dr. Desnica o Obl. Skupštini“, Novo doba, br. 51, 3. 3. 1927., 3.

91 „Rezolucija Oblasne skupštine protiv Nettunskih konvencija“, Jadranska pošta, br. 519, 13. 4. 1927., 3; „Sjednice Oblasne Skupštine“, Novo doba, br. 86, 13. 4. 1927., 3-4.

92 „Dr. Desnica sav bijesan skače na noge, dolazi do klupe disidenata i lupajući šakom o klupe viče prema Drezgi (...) Vidi: „Bura u Oblasnoj Skupštini kod rasprave o Sokolstvu“, Novo doba, br. 121, 25. 5. 1927., 4.

93 „Naša oblasna samouprava“"Novo doba, br. 123, 28. 5. 1927., 3.

94 Zakon o oblasnoj i kotarskoj samoupravi dopuštao je povezivanje nekoliko oblasti. Radićev je cilj bio povezati i uskladiti rad oblasnih skupština na hrvatskom području. Radić je prvotno isticao da središte mora biti u Dubrovniku zbog nedostatka odgovarajuće prostorije za sjednice u Splitu, no ujedinjenje je naposljetku odgođeno. „Radićevska šeprtljanja sa spajanjem oblasti“, Država, br. 282, 23. 2. 1927., 1; Franko MirošEvić, „Politički program skupštine dubrovačke oblasti 1927.-1928.“, Časopis za suvremenu povijest, 24/1992., br. 3, 121-123; H. Matković, Povijest Hrvatske seljačke stranke, 220.

95 „Mjesna organizacija NRS“, Jadranska pošta, br. 584, 4. 7. 1927., 2; „Zbor mjesne organizacije Narodne Radikalne Stranke u Splitu“, Država, br. 311, 27. 7. 1927., 3; „Skupština mjesne organizacije Narodne Radikalne Stranke“, Novo doba, br. 151, 4. 7. 1927., 4.

96 „Split za pok. Ljubom Jovanovićem“, Država, br. 360, 11. 2. 1928., 3; „Parostos za blagopokojnog Ljubu Jovanovića“, Država, br. 362., 18. 2. 1928., 3; „Parastos za blgpk. Ljubom Jovanovićem“, Novo doba, br. 40, 17. 2. 1928., 4.

97 U splitskom tisku nisam našao razloge zbog kojih su radikali samostalno izašli pa ne mogu sa sigurnošću reći koji je tome uzrok. Ipak, zanimljivo je da su i u Zagrebu istupili samostalno na gradskim i parlamentarnim izborima pa je moguće da im druge stranke nisu nudile suradnju ili su htjeli vidjeti koliko imaju svojih pristaša. Vidi: Paulina RADONIĆ VRANJKOviĆ, „Gradski i parlamentarni izbori u Zagrebu 1927. godine“, Radovi Zavoda za hrvatsku povijest, 40/2008., 249-274. 
dalmatinskom okrugu bio je Ljubo Jovanović, a sreski kandidat za spojene kotareve Split - Sinj Ksaver Varda. Među govornicima predizbornog skupa stranke u Splitu, pred približno 200 pristaša, nalazio se Desnica, koji je radikale branio od optužbi za stanje u državi s tvrdnjom da stranka nije cijelo vrijeme sama vodila državu te da je „99\% vremena“ trošila na spas države od njezinih unutarnjih neprijatelja. Hrvatsku inteligenciju optužio je za širenje HSS-a, a samog Radića prozvao je demagogom. Na samom kraju, pomalo dramatično, rekao je da je krajnje vrijeme da se situacija u državi promijeni. Okupljene je pozvao da glasuju za državotvorne stranke kako bi spasili državu. ${ }^{98} \mathrm{U}$ osvrtu na govor Novo doba izrazilo je veliko poštovanje prema osobi i „besjedničkoj vještini“ Uroša Desnice, no nije se slagalo sa sadržajem govora o neodgovornosti radikala, tvrdeći da sami znaju koliko se puta Desnica vraćao razočaran iz Beograda. ${ }^{99}$

Na skupštinskim je izborima NRS u Splitu dobila 364 glasa, odnosno 8,19\%. ${ }^{100}$ Razočarani rezultatom, splitski radikali objavili su članak u Državi, u kojem su naglasili da su vjerovali da će „ispravnim radom te nesebičnim i iskrenim interesom za grad spontano dobiti poštovanje i priznanje građanstva“, odnosno njihovo opredjeljenje za NRS. U tom smislu mnogi su građani primani u stranku, no ti isti na izborima nisu ispunili svoju dužnost. Izbori su pokazali, nastavlja članak, da NRS nije kod Splićana pobrala „nikakvo priznanje za lojalan i ispravan rad ni razumijevanje za njen politički program“. Kao posljedice uslijedit će isključenje svih koji nisu izvršili dužnost, stroži kriteriji pri primanju novih članova te veća pozornost potrebama svojih pristaša. ${ }^{101} \mathrm{U}$ ovom smjeru u prvoj polovici 1928. najavljena je reorganizacija stranke u Splitu. ${ }^{102}$

Nakon izbora nastavljen je rad splitske Oblasne skupštine, no sada u znatno mirnijoj atmosferi. Desnica je isticao konstruktivniji rad Skupštine, no ponovno se protivio prijedlogu proračuna držeći da je on nerealan u nekim dijelovima, no kao i u prethodnom slučaju proračun je ipak prihvaćen. ${ }^{103}$

98 „Kandidatska lista NRS“, Jadranska pošta, br. 620, 16. 8. 1927., 2; „Sreski kandidati Radikalne Stranke“, Država, br. 312, 30. 7. 1927., 2; „Radikalski kandidati za srezove Split, Sinj, Supetar“, Novo doba, br. 174, 30. 7. 1927., 4; „Konferencija NRS u hotelu Belleuve“, Jadranska pošta, br. 639, 6. 9. 1927., 4; „Izborni zbor radikalne stranke u Splitu“, Novo doba, br. 206, 6. 9. 1927., 2; „Veliki zbor Narodne Radikalne Stranke u Splitu“, Država, br. 322, 7. 9. 1927., 1.

99 „Predizborni zborovi u Splitu: Zbor NRS“, Novo doba, br. 208, 8. 9. 1927., 3.

100 „Rezultati izbora za Narodnu skupštinu u Dalmaciji i cijeloj zemlji: Grad Split“, Jadranska pošta, br. 644, 12. 9. 1927., 1 .

101 „Radikalna stranka i Split“, Država, br. 324, 14. 9. 1927., 2.

102 „Reorganizacija Narodne Radikalne Stranke“, Država, br. 365, 3. 3. 1928., 3; „Reorganizacija mjesne organizacije Narodne Radikalne Stranke“, Novo doba, br. 55, 6. 3. 1928., 4.

103 „Prva sjednica Oblasne skupštine“, Jadranska pošta, br. 691, 7. 11. 1927., 3; „Sjednica Splitske Oblasne Skupštine“, Novo doba, br. 259, 7. 11. 1928., 3-4; „Rad Oblasne Skupštine“, Jadranska pošta, br. 693, 9. 11. 1927., 3; „Sjednica Splitske Oblasne Skupštine“, Novo doba, br. 263, 11. 11. 1927., 4; „Budžet naše Oblasne Skupštine“, Novo doba, br. 302., 31. 12. 1927., 4-5; „Iz Oblasne Skupštine“, Jadranska pošta, br. 1, 2. 1. 1928., 2. 


\section{Od atentata u Narodnoj SkUpštini DO UVOĐENJA DIKTATURE}

Narodna radikalna stranka u Splitu prolazila je u prvoj polovici 1928. kroz relativno mirno razdoblje sve do atentata Puniše Račića na Stjepana Radića i ostale hrvatske zastupnike u Narodnoj skupštini. ${ }^{104}$ Splitsko je općinsko vijeće na izvanrednoj sjednici oštro osudilo atentat. ${ }^{105}$ Posljedica atentata bilo je i raspuštanje splitskog općinskog vijeća zbog odluke općinske većine o apstinenciji prilikom nadolazeće proslave Vidovdana. Odluku o raspuštanju i uvođenju komesarijata donio je Veliki Župan Ivo Perović (član NRS-a), a obrazložio ju je „demonstrativnim nesudjelovanjem u proslavi Vidovdanskog praznika“. ${ }^{106}$

Apstinencija splitske općine u proslavi Vidovdana nagnala je Državu na komentar kako je riječ o nedostatku „duboke i istinske nacionalne svijesti grada“. U proslavi su sudjelovali samo oni koji iskreno vole domovinu i kralja, zbog čega je ona, kao najiskrenija, bila najljepša od svih dotadašnjih proslava u Splitu, zaključuje Država. ${ }^{107}$ Ovaj natpis izazvao je Novo doba na odgovor da se građanstvu Splita ne može spočitavati pomanjkanje patriotskog osjećaja te da bi zbog svih događaja kojima su „napravili dosta zla“ radikalima bilo bolje kada bi „pustili Split i njegove građane na miru“. ${ }^{108} \mathrm{Uz}$ Novo doba na pisanje Države reagirali su Obzor i Pobeda, koji su govorili o „opravdanom revoltu čitavog Splita“, odnosno pozvali list da otvoreno imenuju ljude koje su držali odgovornim za nedostatak nacionalne svijesti u Splitu. ${ }^{109}$

U polemiku se potom uključio Uroš Desnica, koji je preko Države oštro optužio Novo doba za plemensku, vjersku mržnju i „novodobaštinu“, termin kojim je opisao mijenjanje političkog pravca lista. Desnica je tvrdio da je Novo doba u ranijim izborima ${ }^{110}$ zvalo upomoć Narodnu radikalnu stranku te se „koristilo njenom naklonošću i beneficijama za Split i splitsko građanstvo" mnogo više nego što je Split to zaslužio, a zaključkom je poručio da su radikali punopravni građani svih dijelova države pa tako i Splita. ${ }^{111}$

U odgovoru je Novo doba istaknulo da su za autora članka ranije vjerovali da u političkoj borbi ne prelazi na „lične uvrede“. Desničine tvrdnje o „političkom vrludanju lista“ odba-

$\overline{104}$ Više o atentatu vidi u: Zvonimir Kulundžić, Atentat na Stjepana Radića, Zagreb 1927.; Nadežda Jovanović, „Pri$\log$ proučavanja odjeka atentata u Narodnoj skupštini 20. juna 1928.“, Časopis za suvremenu povijest, 2/1970., br. 1, 61-76.

105 SVKST, ZOV od 23. lipnja 1928., M - 611/III - a; „Žalobna manifestacija grada Splita: Rezolucija Općinskoga Vijeća“, Novo doba, br. 146, 23. 6. 1928., 4-5.

106 Prijedlog o apstinenciji donijeli su vijećnici HSS-a, SDS-a i HFSS-a uz potporu HPS-a. Gradonačelnik Tartaglia odlučio je predati ostavku na svoju funkciju jer je vjerovao da „prema parlamentarnom principu“ mora provesti odluku o apstinenciji što je u suprotnosti s njegovim stavom. Uz Tartagliu, ostavku su predala i tri člana općinske uprave, među njima i Eduard Grgić. Vidi: Marijan BulJan, „Splitski općinski izbori 1928.“, Historijski zbornik, 66/2013., br. 2, 335-336.

107 „Proslava Vidovdana u Splitu“, Država, br. 396, 4. 7. 1928., 3-4.

108 „Radikalski organ Država“, Novo doba, br. 156, 5. 7. 1928., 4.

109 „Raspust splitskoga gradskoga zastupstva“, Obzor (Zagreb), br. 181, 9. 7. 1928., 5; „Radikalska impertinencija“, Pobeda (Split), br. 27, 6. 7. 1928., 2.

110 Ovime Desnica misli na oblasne skupštine 1927. kada je Novo doba uoči izbora pozvalo sve stranke da izađu jednom zajedničkom listom kako 3 oblasna zastupnika koje je birao grad Split ne bi bila komunistička. Vidi: „Grad Split i Oblasni izbori“, Novo doba, br. 289, 16. 12. 1926., 4.

111 „Novom Dobu“, Država, br. 397, 7. 7. 1928., 1-2. 


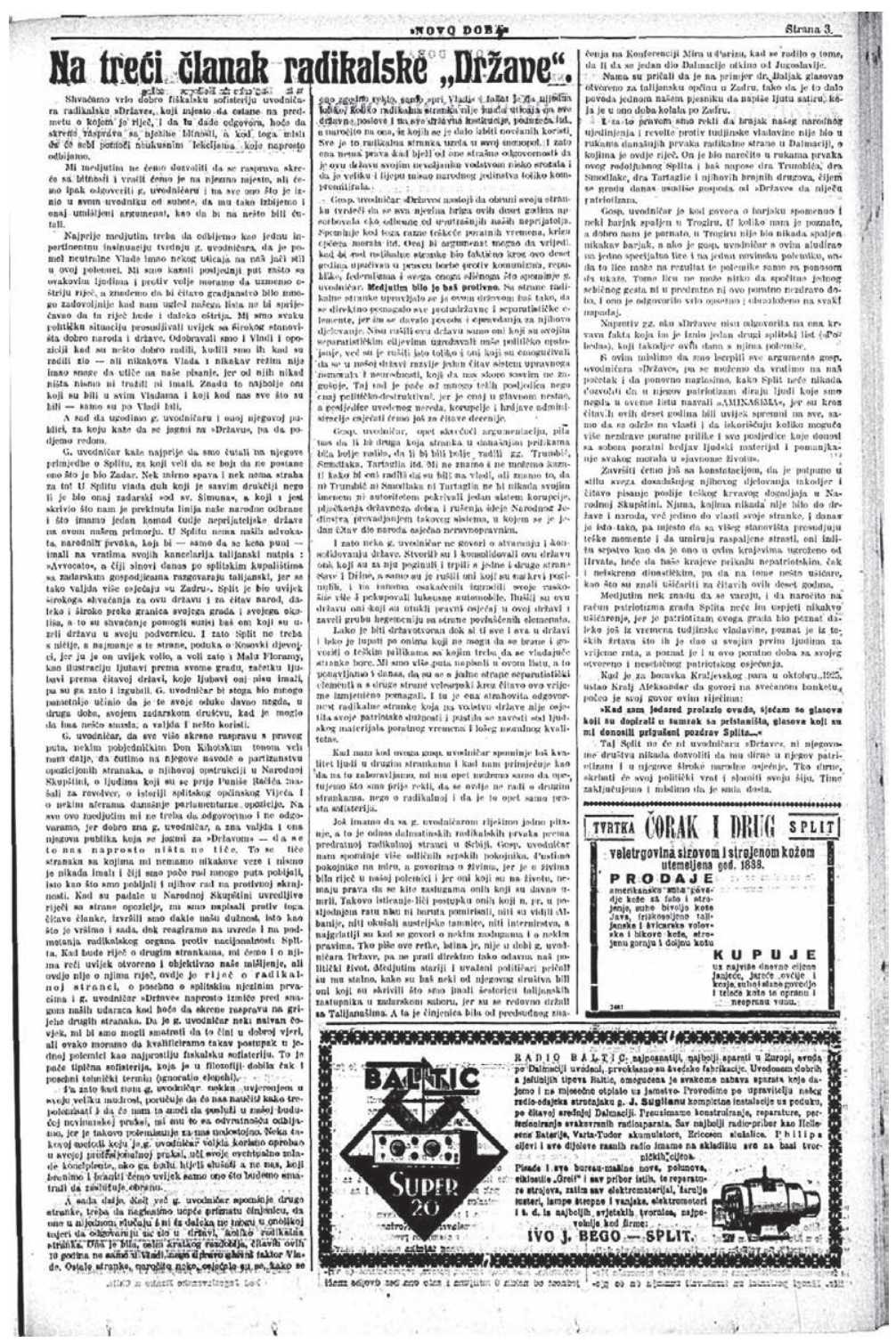

Sl. 2. Polemika između Novog doba i Države

čene su, dok su radikali optuženi za stanje u državi, s podsjetnikom da je i sam Desnica uoči prethodnih parlamentarnih izbora govorio o nužnosti promjene državnog kursa. Na samom kraju je Novo doba ponovno zatražilo poštovanje prema Splitu i njegovom građanstvu, koje je uvijek bilo „visoko nacionalno“.112

Uroš Desnica je u novom obraćanju tvrdio da su radikali za državu dali više nego „Prečani“ te da su im stranačke kolege zamjerali „splitsku nježnost“ zbog veće pozornosti posvećivane Splitu nego što je on to zaslužio pa je „samo mržnja mogla pozvati radikale, to jest 
Srbe“ da puste Split na miru. Želja je radikala, zaključio je, da se Split „ne zatvori u svoju ljusku“, već da bude predstavnik cijele oblasti i glavni grad na Jadranu. ${ }^{113}$

Novo doba ponovno je istaknulo da je Desničino pisanje pokazalo da kod radikala ne postoje pojedinci koji se „uzdižu iznad običnog nivoa“. Stranka je optužena za korupciju i rušenje narodnog jedinstva, a čast Splita ponovno je žestoko branjena isticanjem da grad nikada nije podignuo glas protiv Srbije i Srba. „Uvodničar Države“ i njegova bliža okolina, poručuje Novo doba, nemaju nikakve zasluge u razvoju Splita, već, dapače, „stalnim neukusnim zadirkivanjima i porukama" u gradu izazivaju najveće ogorčenje. ${ }^{114}$

Novim člankom Desnica je rekapitulirao dosadašnju polemiku i ponovno opravdao politiku radikala u državi, a u raspravu se uključila i orjunaška Pobeda, koja je tvrdila da radikali u Splitu uživaju posebnu antipatiju jer se za razliku od ostalih stranaka njezini članovi prema Splitu i njegovim građanima ponašaju kao gospodari. ${ }^{115}$

U nastavku polemike s Novim dobom Desnica je isticao da radikali vole Split i optuživao Novo doba za štetnu ideologiju kojom protiv NRS razdražuje lokalni regionalizam. Polemiku je držao opravdanom vjerujući da je njome Novo doba pokazalo prave osjećaje prema radikalima i Srbiji i povuklo se pred njegovim argumentima. ${ }^{116}$

S druge strane Novo doba je u nekoliko navrata sebi prisvajalo pobjedu u polemici, uz daljnje optuživanje radikala za stanje u državi, a neke njihove članove za prijeratnu suradnju s Talijanima, i dalje braneći ugled Splita. „Uvodničar Države“ optužen je da je prije rata kao odvjetnik na vratima svoga ureda držao i talijanski natpis te da je zbog svog pisanja u ovoj polemici izgubio veliko poštovanje lista. ${ }^{117}$

Splitski općinski izbori 1928. raspisani su za sredinu studenog 1928. Držanje mjesnih radikala na izborima isprva nije bilo definirano. Zagrebački Obzor tvrdio je da su se dvoumili između podrške Tartaglinoj listi ${ }^{118}$ ili samostalnog nastupa kako bi se stranka „prebrojala“ u Splitu. ${ }^{119}$ Potonja mogućnost je pobijedila pa je za nosioca NRS na splitskim općinskim izborima postavljen Jozo Arambašin, ${ }^{120}$ dok je Uroš Desnica zauzeo peto mjesto zamjenika. ${ }^{121}$ Pitanje je koliko bi druge stranke koje su činile Tartaglinu listu pristale surađivati s NRS-om jer okolnosti poput nepopularnosti stranke, atentata u Narodnoj skupštini i velike polemike s Novim dobom oko „patriotizma“ Splita radikalima nikako nisu išli u prilog.

113 „Opet Novom Dobu“, Država, br. 398, 11. 7. 1928., 1.

114 „Replika g. uvodničaru Države“, Novo doba, br. 162, 12. 7. 1928., 3.

115 „Bez treće nema sreće“, Država, br. 399, 14. 7. 1928., 1; „Odgovor Državi“, Pobeda, br. 28, 13. 7. 1928., 1-2; „Replika Državi“, Pobeda, br. 29, 20. 7. 1928., 2.

116 „Parastos“, Država, br. 401, 21. 7. 1928., 1; „Posmrtna počast Novom dobu“, Država, br. 403, 28. 7. 1928., 1-2; „Konac jedne polemike“, Država, br. 405, 4. 8. 1928., 1.

117 „Na treći članak radikalske Države“, Novo doba, br. 167, 17. 7. 1928., 3; „U ovoj pasjoj vrućini: Naš četvrti odgovor g. uvodničaru Države“, Novo doba, br. 174, 24. 7. 1928., 3; „Bit ćemo kratki: na peti članak radikalske Države“, Novo doba, br. 181, 31. 7. 1928., 3; „Epilog polemike sa Državom“, Novo doba, br. 188, 7. 8. 1928., 3.

118 I na ovim općinskim izborima ponovno se javila ideja o stvaranju jedne „višestranačke“ izborne liste, koja bi u prvom redu isticala komunalnu politiku. Ivo Tartaglia ponovno je postavljen za nositelja te liste. Vidi: M. BuLJAN, „Splitski općinski izbori 1928.“, 342.

119 „Radikali i općinski izbori u Splitu“, Obzor, br. 284, 22. 10. 1928., 7.

120 Jozo (Joso) Arambašin (1861. - 1945.), liječnik. Bavio se higijenom i zdravstvenim prosvjećivanjem, a bio je i predsjednik Slobodne organizacije liječnika Dalmacije. P. PožAr, Znameniti i zaslužni Splićani, 34.

121 „Lista Narodne Radikalne Stranke“, Jadranska pošta, br. 253, 31. 10. 1928., 2; „Lista Narodne Radikalne Stranke“, Država, br. 427, 31. 10. 1928., 1. 
Desničino mjesto na radikalskoj listi također je zanimljivo. Radi li se o odluci vrha stranke da ga zbog ranije spomenute polemike postavi na što niže mjesto kako ne bi štetio izbornom rezultatu, Desničinoj želji da se ne eksponira nego da odlučuje iz prikrajka, ili je riječ o nečem drugom, ostaje otvoreno pitanje. Samostalni istup stranke ipak nam pruža zanimljiv uvid u to koji su to društveni slojevi u Splitu podržavali pojedine političke stranke.

\begin{tabular}{|l|l|l|l|l|l|l|}
\hline ZANIMANJA & $\begin{array}{l}\text { VISOKOOBRAZOVANE } \\
\text { OSOBE (\%) }\end{array}$ & $\begin{array}{l}\text { TRGOVCI I } \\
\text { OBRTNICI (\%) }\end{array}$ & TEŽACI (\%) & $\begin{array}{l}\text { DRŽAVNI } \\
\text { ČINOVNICI (\%) }\end{array}$ & $\begin{array}{l}\text { UMIROVLJENICI } \\
(\%)\end{array}$ & $\begin{array}{l}\text { RADNICI } \\
\text { I OSTALA } \\
\text { ZANIMANJA (\%) }\end{array}$ \\
\hline \hline Gradska SDS & 14,63 & 48,78 & 2,44 & 21,95 & 12,2 & - \\
\hline Tartaglia & 35,37 & 34,15 & 21,95 & 3,66 & 3,66 & - \\
\hline HSS & 4,88 & 25,61 & 51,22 & 15,85 & 1,22 & 1,22 \\
\hline HFSS & 9,76 & 51,21 & 26,83 & 2,44 & 6,1 & 3,66 \\
\hline NRS & 29,27 & 29,27 & - & 34,15 & 4,88 & 2,44 \\
\hline RSRS ${ }^{122}$ & - & 32,93 & 62,2 & - & - & 4,88 \\
\hline HPS & 25,6 & 32,93 & 14,63 & 7,32 & 8,54 & 10,98 \\
\hline Seoska SDS & 3,75 & 26,25 & 54,88 & 3,75 & 2,5 & 7,5 \\
\hline
\end{tabular}

Tablica 1. Zanimanja kandidata vodećih stranaka ${ }^{123}$

U odnosu na ostale stranke NRS pokazuje znatna odstupanja u pojedinim zanimanjima: prezastupljenost u broju državnih činovnika i podzastupljenost u broju težaka Nitko od kandidata i zamjenika nije bio „deklariran“ kao težak, za razliku od opozicijskih stranaka u kojima su težaci činili od 25 do 60\% svih kandidata stranke. Čini se da NRS u Splitu ničim nije privlačila splitske težake. Politički protivnici često su radikalima spočitavali da svoje glasove dobivaju od državnih činovnika u zamjenu za posao, ${ }^{124}$ a gotovo $35 \%$ kandidata činovnika te navode čini vjerodostojnijima. Ostaje otvoreno pitanje što je s gotovo $30 \%$ osoba sa završenim fakultetom, odnosno $30 \%$ trgovaca i obrtnika. Jesu li se oni pridružili radikalima iz iskrene vjere u program i rad stranke ili je riječ o karijeristima koji su stupili u stranku iz materijalnih razloga?

Split će na izborima, vjerovali su radikali, odlučiti hoće li nastaviti život kao „predstavnik jugoslavenske misli i pobornik nacionalnog jedinstva Hrvata i Srba“ ili će postati „veliko selo“. Glasove su očekivali od „svih ostalih vjernih ideji narodnog jedinstva“ koji žele dobro i napredak Splita, uvjereni da će „ispravan rad NRS pobijediti“. ${ }^{125}$ No radikali u predizbornoj kampanji nisu održali nijedan zbor ili izborni sastanak te je bilo upitno na čemu temelje svoj optimizam.

\footnotetext{
$\overline{122}$ Republikanski savez radnika i seljaka - ime pod kojim su istupili komunisti.

123 Izvori: Jadranska pošta, 22. 10. 1928., 3; 23. 10. 1928., 2; 26. 10. 1928., 3; 29. 10. 1928., 3; 31. 10. 1928., 2; Novo doba, br. 277, 2. 11. 1928., 4.

124 „Zašto smo porasli“, Naše selo (Split), br. 18, 26. 11. 1928., 1.

125 „Općinski izbori u Splitu“, Država, br. 429, 10. 11. 1928., 3; „Samostalci i radićevci“, Država, br. 431, 17. 11. $1928 ., 2$.
} 
Na splitskim općinskim izborima 1928. NRS u Splitu osvojila je 385 glasova, odnosno 7,29\%, a u cjelokupnoj splitskoj općini 5,87\%. U splitsko općinsko vijeće ušla su dva njezina vijećnika: Jozo Arambašin i Jovo Margetić. ${ }^{126}$ Radikali su se žalili na izborni teror nad njezinim pristašama, no bili su zadovoljni rezultatima zbog „lijepe afirmacije“, iako su dobili još manje glasova nego 1927. kada je uslijedio ranije spomenuti članak o potrebi reorganizacije stranke. Split je, zaključili su, „pokazao svoje pravo lice“ izjasnivši se za „politiku uskog hrvatskog separatizma i destruktivnu politiku komunizma“ te je od „najjugoslavenskijeg grada“ postao „separatističko-komunistički grad“ ${ }^{127}$

Desetu godišnjicu dolaska srpske vojske Split je potpuno zaboravio, pisala je Država nakon izbora, vjerujući da je takav zaborav moguć jedino u sredini „koja nikad nije bila prožeta istinskim nacionalnim duhom ". ${ }^{128}$ Arambašin je kao dobni predsjednik na sjednici novoga Općinskog vijeća u govoru istaknuo zasluge bivše uprave u razvoju Splita, a poslije je predložio da se pošalje brzojav kralju, na što je novi gradonačelnik Josip Berković1 ${ }^{129}$ odgovorio da je to već napravila općinska uprava. Ovaj potez Jadranska Pošta tumačila je pokušajem NRS da sebi pokuša prisvojiti „pečat dinastičnosti“ i oštro ga je kritizirala. Potom je Država zažalila zbog stanja u Splitu i nestanka njegovog „starog patriotizma“. ${ }^{130}$

U sjeni splitskih općinskih izbora Oblasna skupština nastavila je sa zasjedanjem. Zanimljivo je da se na prvim sjednicama nije nalazio Desnica, koji je u to vrijeme boravio u radikalskom klubu u Beogradu, gdje je govorio o agrarnom pitanju u Dalmaciji. ${ }^{131} \mathrm{U}$ kasnijim sjednicama Desnica se rijetko javljao za riječ, a možemo primijetiti da Novo doba više nije detaljno donosilo izvatke iz njegovih govora. Razlog tome možemo naći u ranije spomenutoj polemici.

Kriza nastala u zemlji zbog skupštinskog atentata poslužila je kralju Aleksandru I. Karađorđeviću kao povod za uvođenje diktature 6. siječnja 1929. Sve političke stranke kraljevom su odlukom zabranjene. ${ }^{132} \mathrm{U}$ zadnjem obraćanju preko Države Desnica je naglasio da prihvaća kraljevu odluku, uz uvjerenje da su radikali, za razliku od opozicijskih stranaka, ipak bili drugačija stranka koja će se u odgovarajućim uvjetima ponovno aktivirati. ${ }^{133}$

$\overline{126}$ U splitskoj općini sveukupno je glasovalo 67,44\% birača, a više glasova od radikala dobili su: HSS, SDS, HFSS, komunisti i lista Ive Tartaglie. M. BulJan, „Splitski općinski izbori 1928.“, 355.

127 „U gradu“, Jadranska pošta, br. 268, 19. 11. 1928., 1; „Općinski izbori u Splitu“, Država, br. 432, 21. 11. 1928., 1; „Zašto smo porasli“, Naše selo, br. 18, 26. 11. 1928., 1.

128 „Desetgodišnjica dolaska srpske vojske u Split“, Država, br. 433, 24. 11. 1928., 1.

129 Josip Berković (1885. - 1968.?), liječnik i diplomat. U međuratnom razdoblju jedan od najistaknutijih djelatnika HSS-a u Dalmaciji, parlamentarni zastupnik na izborima 1935. i 1938. U razdoblju Drugog svjetskog rata pristupa ustaškom pokretu pa postaje potpredsjednik Hrvatskog državnog sabora. Nakon rata emigrira u Argentinu. Milan Pojić, „Josip Berković“, Tko je tko u NDH (ur. Darko Stuparić), Zagreb 1997., 35.

130 SVKST, ZOV od 25. studenog 1928., M - 611/III - a; „Živio Hrvatski Načelnik Dr. J. Berković, Jadranska pošta, br. 274, 26. 11. 1928., 1-2; „Prva sjednica novoga Općinskog Vijeća“, Novo doba, br. 301, 26. 11. 1928., 2-3; „Ažanprovokaterstvo“, Jadranska pošta, br. 274, 26. 11. 1928., 2; „Prva sjednica novoga Općinskog Vijeća“, Novo doba, br. 301, 26. 11. 1928., 2-3; „Nova općinska uprava u Splitu“, Država, br. 434, 29. 11. 1928., 3.

131 „Dr. Desnica pred radikalskim klubom u Beogradu“, Jadranska pošta, br. 260, 9. 11. 1928., 1.

132 „Mom dragom Narodu“, Službeni glasnik (Beograd), br. 2, 6. 1. 1929., 1. Više o uspostavi diktature vidi u: Ljubo Boban, Maček i politika Hrvatske seljačke stranke, sv. 1, Zagreb 1974., 40-48; Rudolf Horvat, Hrvatska na mučilištu, Zagreb 1992., 425-431; Nedim ŠARAC, Uspostavljanje šestojanuarskog režima 1929. godine s posebnim osvrtom na Bosnu i Hercegovinu, Sarajevo 1975.

133 „Našim prijateljima“, Država, br. 444, 2. 2. 1928., 1. 


\section{ZAKLJUČAK}

Kao što smo vidjeli na prethodnim stranicama, Narodna radikalna stranka u Splitu imala je gotovo zanemarivu ulogu. Uz općenitu nepopularnost radikala u hrvatskim krajevima i malom broju Srba potencijalnih glasača ${ }^{134}$ skromnoj ulozi stranke u Splitu pogodovalo su još dva razloga. Prvi je što stranka tijekom godine nije održavala redovite sastanke i organizirala konferencije i akcije kojima bi privukla potencijalne glasače niti je održavala kontakte s postojećima. Najave o reorganizaciji mjesne organizacije stranke kao da nikada nisu provedene jer se ne uočavaju nikakve razlike u djelovanju stranke. Pojedine rijetke konferencije obično bi bile usmjerene širem području, a ne isključivo Splitu. Drugi razlog također je sličan: iako je mjesto izlaženja bilo Split, radikalska Država gradu Splitu nije posvećivala veću pozornost. U slučajevima kada bi to i učinila, obično bi to bilo u negativnom kontekstu jer bi Splitu spočitavala manjak patriotizma. Radikali su nedostatak većeg broja glasova pokušali kompenzirati koalicijom s drugim strankama na izborima, no samostalan istup značio je gotovo sigurno manje od $10 \%$ dobivenih glasova.

Uroš Desnica pripadao je istaknutom krugu radikalskih imena koja su se javljala u Splitu, no stječe se dojam da je u nekim situacijama više volio djelovati iza kulisa. Izuzetak je splitska Oblasna skupština, u kojoj se posebno isticao od svih opozicijskih zastupnika. U svojemu nastupu, osobito prema HSS-u, držao se „visoko“ te im se često izrugivao i optuživao ih za nepoznavanje zakona. Njegovo pisanje pod pseudonimom u Državi, kojim je oštro kritizirao i izrugivao se Radiću i Trumbiću, ponekad je prerastalo u ad hominem napade. Desničina polemika s Novim dobom 1928., koja i zaključuje njegovo razdoblje u Splitu do uvođenja diktature, zaslužuje posebnu pozornost. Člancima tiskanima u Državi Desnica je nepotrebno zaoštravao situaciju i time stranci još više umanjio uspjeh na nadolazećim izborima. Bez obzira na to kakvo pisanje imalo Novo doba, optužiti jedan grad za nedostatak patriotizma u veoma osjetljivoj političkoj situaciji izazvanoj tragičnim događajima u Narodnoj skupštini pokazalo se lošim političkim potezom, koji je bacio mrlju na Desničin boravak u Splitu 1920-ih.

\section{$\cos$}

\section{Uroš Desnica and the People’s Radical Party in i92os Split According to the Periodical Literature IN SPLIT}

Although it published the party newspaper Država and took part in every general, municipal and county election during the 1920s, the People's Radical Party (NRS) never gained a significant fo-

134 Zdravka Jelaska Marijan vjeruje da se „s priličnom sigurnošću“ može utvrditi da je hrvatsko stanovništvo u Splitu 1921. činilo „između 87,5\% i 88,5\% stanovništva“, a na području splitske općine „između $90 \%$ i $91 \%$ stanovništva“.

Z. Jelaska Marijan, Grad i ljudi, 55. 
oting in Split or achieved a significant electoral result. This paper looks into its operation during this period, with special consideration given to the work of Uroš Desnica, Vladan Desnica's father. The party attempted to mitigate its modest electoral results by building coalitions with like-minded Yugoslav-oriented parties, but the lack of a more promising result boiled down to the fact that it lacked a more intensive contact with potential voters and the population structure which was predominantly Croatian. One of the party's more prominent members in Split was the lawyer Uroš Desnica, who had distinguished himself by stepping into confrontations with members of the Croatian Peasant Party (HSS) in the Split County Assembly since 1927 onwards. The People Radical Party's relationship toward Split is especially interesting: while it had previously been called the "most Yugoslav city", the strengthening of Croatian parties led them to change their thinking and begin calling Split a "separatist-communist city" who had "renounced" its earlier Yugoslavdom. Uroš Desnica followed this path, and during the summer of 1928 he entered into a discussion with the leading Serbian daily Novo doba on the topic of Split patriotism. With the introduction of King Alexander's dictatorship in 1929 all political parties, among them the People's Radical Party, were abolished.

Keywords: Uroš Desnica, Split, People’s Radical Party, elections, Država, Split County Assembly

\title{
$\cos$
}

\section{Neobjavljeni izvori}

Sveučilišna knjižnica u Splitu (SVKST)

Arhivska ostavština Ante Trumbića (TO)

Zapisnici sa sjednice općinskog vijeća u Splitu (ZOV)

\section{Periodika}

\author{
Država (Split) \\ Jadran (Split) \\ Jadranska pošta (Split) \\ Naše selo (Split) \\ Novo doba (Split) \\ Obzor (Zagreb) \\ Pobeda (Split) \\ Pučki list (Split)
}

\section{Literatura}

Ljubomir AnTić, „Hrvatska federalistička seljačka stranka“, Radovi instituta za hrvatsku povijest, 15/1982., 163-222.

Ivo BANaC, Nacionalno pitanje u Jugoslaviji: porijeklo, povijest, politika, Zagreb 1995.

Ljubo Boвan, Maček i politika Hrvatske seljačke stranke 1928-1941, sv. 2, Zagreb 1974.

Ljubo Boban, „Prilozi za političku biografiju don Frane Bulića (1914-1934)“, Radovi Zavoda za hrvatsku povijest, 18/1985., 167-214.

Ante Bralić, Zadar u doba Prvog svjetskog rata, doktorska disertacija, Zadar 2005. 
Marijan Buljan, „Splitski općinski izbori 1928.“, Historijski zbornik, 66/2013., br. 2, 329-364.

Antoni Cetnarowicz, Narodni preporod u Dalmaciji: od slavenstva prema modernoj hrvatskoj i srpskoj nacionalnoj ideji, Zagreb 2006.

Marjan Diklić, Pravaštvo u Dalmaciji do kraja Prvog svjetskog rata, Zadar 1998.

Arsen Duplančić, „Izvori za povijest masonstva u Splitu“, Croatica Christiana Periodica, 16/1992., br. 30, 104-115.

Tereza Ganza-Aras, Politika „novog kursa“ dalmatinskih pravaša oko Supila i Trumbića, Split 1992.

Branislav Gligorijević, Demokratska stranka i politički odnosi u Kraljevini Srba, Hrvata i Slovenaca, Beograd 1970.

Branislav Gligorijević, Parlament i političke stranke u Jugoslaviji (1919-1929), Beograd 1979.

Josip Horvat, Politička povijest Hrvatske, sv. 2, Zagreb 1989.

Rudolf Horvat, Hrvatska na mučilištu, Zagreb 1992.

Hrvatski biografski leksikon (HBL), sv. V, Zagreb 2002.

Hrvatski biografski leksikon (HBL), sv. VI, Zagreb 2005.

Aleksandar Jakir - Norka Machiedo-Mladinić (ur.), Izabrani spisi Ive Tartaglie, Split 2013.

Zdravka Jelaska Marijan, Grad i ljudi: Split 1918.-1941., Zagreb 2009.

Zdravka Jelaska Marijan, „Uspostava Zemaljske vlade za Dalmaciju u Splitu 2. studenoga 1918“, 1918. u hrvatskoj povijesti: zbornik (ur. Romana Horvat), Zagreb 2012., 203-212.

Zdravka Jelaska Marijan, „Zemaljska vlada za Dalmaciju (2. studenoga 1918. - 20. siječnja 1919.), Godina 1918: prethodnice, zbivanja, posljedice. Zbornik radova s medunarodnoga znanstvenog skupa (ur. Zlatko Matijević), Zagreb 2010., 155-170.

Nadežda Jovanović, „Prilog proučavanja odjeka atentata u Narodnoj skupštini 20. juna 1928.“, Časopis za suvremenu povijest, 2/1970., br. 1, 61-76.

Šimun Jurišić, Glasoviti Splićani, Split 2008.

Petar Krolo, „Ante Trumbić i općinski izbori u Splitu 1926. i 1928. godine“, Život i djelo Ante Trumbića: prilozi sa znanstvenog skupa (ur. Ljubo Boban i Ivan Jelić), Zagreb 1991., 137-151.

Ivanka Kuić, „Novo doba - najvažniji splitski i dalmatinski list između dva rata“, Kulturna baština, 39/2013., 113-138.

Zvonimir KulundžIć, Atentat na Stjepana Radića, Zagreb 1967.

Rene Lovrenčić, Geneza politike „novog kursa“, Zagreb 1972.

Norka Machiedo Mladinić, Životni put Ive Tartaglie, Split 2001.

Zlatko Matijević, „Kazalo osoba“, Fontes: izvori za hrvatsku povijest, 14/2008., 597-621.

Hrvoje Matкović, Svetozar Pribićević i Samostalna demokratska stranka do šestojanuarske diktature (1924-1929), Zagreb 1972.

Hrvoje Matković, Povijest Hrvatske seljačke stranke, Zagreb 1999.

Hrvoje Matković, Povijest Jugoslavije (1918 - 1991 - 2003), Zagreb 2003.

Franko Mirošević, Počelo je 1918 ... : Južna Dalmacija 1918-1929., Zagreb 1992.

Franko MirošEvić, „Radićevi govori u Dalmaciji 1926. godine“, Radovi Zavoda za povijesne znanosti HAZU u Zadru, 50/2008., 300-307.

Franko MirošEvić, „Politički program skupštine dubrovačke oblasti 1927.-1928.“, Časopis za suvremenu povijest, 24/1992., br. 3, 117-128.

Hrvoje Morović, Grada za bibliografiju splitske periodike, Split 1968.

Šime PeričIĆ, „Prilog poznavanju talijanske okupacije Dalmacije od 1918. do 1923. godine“, Radovi Instituta JAZU u Zadru, 20/1973., 7-48. 
Ivo Perić - Hodimir Sirotković, „Politička djelatnost i politički lik Josipa Smodlake“, u: Josip Smodlaka, Izabrani spisi (prir. Ivo Perić i Hodimir Sirotković), Split 1989., 9-203.

Ivo Petrinović, Ante Trumbić: politička shvaćanja i djelovanje, Split 1991.

Jaroslav ŠIDAK i dr. Povijest hrvatskog naroda 1860. - 1914., Zagreb 1968.

Petar PožAr, Znameniti i zaslužni Splićani, Split 2001.

Branislav Radica, Novi Split: monografija grada Splita od 1918-1930 godine, Split 1931.

Paulina RADONiĆ VRANJKOviĆ, „Gradski i parlamentarni izbori u Zagrebu 1927. godine“, Radovi Zavoda za hrvatsku povijest, 40/2008., 249-274.

Drago RoksAndić, „Dr. Uroš Desnica 1918. - 1921.: životopisne nedoumice na raskrižju epoha“, Spalatumque dedit ortum: zbornik povodom desete godišnjice Odsjeka za povijest Filozofskog fakulteta u Splitu (ur. Ivan Basić i Marko Rimac), Split 2014., 499-511.

Drago Roksandić, „Zatvaranje kruga: Dr Uroš Desnica (Obrovac, 28. VII 1874 - Split, 13. VII 1941)“, Spomenica dr Danice Milić (ur. Bojana Miljković-Katić), Beograd 2014., 295-314.

Josip Smodlaka, Zapisi dra Josipa Smodlake (ur. Marko Kostrenčić), Zagreb 1972.

Nikša Stančić, Hrvatska nacija i nacionalizam u 19. i 20. stoljeću, Zagreb 2002.

Nedim ŠARAC, Uspostavljanje šestojanuarskog režima 1919. godine s posebnim osvrtom na Bosnu $i$ Hercegovinu, Sarajevo 1975.

Dragovan ŠEPIĆ, Italija, saveznici i jugoslavensko pitanje 1914-1918., Zagreb 1970.

Zdenka Šımončıć-BoBetкo, „Agrarno pitanje u Dalmaciji između dva rata (1918-1941“, Povijesni prilozi, 8/1989., 91-141.

Ferdo Šıšić, Jadransko pitanje na konferenciji mira u Parizu. Zbirka akata i dokumenata, Zagreb 1920.

Marina ŠTAmbuk-ŠKalić - Zlatko Matijević, „Narodno vijeće Slovenaca, Hrvata i Srba u Zagrebu 1918-1919. (izabrani dokumenti)“, Fontes: izvori za hrvatsku povijest, 14/2008., 71-596.

Tko je tko u NDH (ur. Darko Stuparić), Zagreb 1997. 